\title{
Chapter 2 \\ Microbiota and Biochemical Processes \\ Involved in Biodeterioration of Cultural \\ Heritage and Protection
}

\author{
Ji-Dong Gu and Yoko Katayama
}

\begin{abstract}
The world cultural heritage sites face new challenges for an effective protection and management because of destruction and damage initiated by both natural and anthropogenic causes. Fresh rock and sandstone surfaces of buildings are quickly colonized and covered by a layer of microorganisms, including phototrophs, lithotrophs, and heterotrophs to form a biofilm that alters the local conditions of the stone surfaces, especially under the favorable tropical climate conditions for autotrophic microorganisms and plants. Biofilms had been studied with indigenous or pure cultures of isolated microorganisms, but the selective ones that contribute to deterioration of the cultural heritage cannot be confirmed easily. Currently, highthroughput sequencing and metegenomics analyses are capable of obtaining microbial community and composition in great depth, but they also suffer from similar weakness unable to identify the culprits in the community. With these as background, this article presents a different approach by focusing on the biochemical processes and the responsible microorganisms involved to reveal the destruction processes for management and protection. Among these different functional groups of microorganisms, lichens are known as pioneering rock-decomposing microorganisms, and both sulfur-oxidizing bacteria and fungi participate in the decomposition of sandstone via sulfur cycling and initiation of salt attack of the stone afterward, resulting in defoliation and cracking of stone. Other microorganisms including ammonia-oxidizing bacteria and archaea, especially the latter, have been recently detected on sandstone monuments providing evidence on the new organisms involved in the deterioration of cultural heritage and buildings. In addition, fungi can colonize the surfaces of the matured biofilms and play a new role in the removal
\end{abstract}

\footnotetext{
J.-D. Gu $(\bowtie)$

Environmental Engineering, Guangdong Technion Israel Institute of Technology, Shantou, Guangdong, People's Republic of China

Laboratory of Environmental Microbiology and Toxicology, School of Biological Sciences, The University of Hong Kong, Hong Kong SAR, People's Republic of China

e-mail: jidong.gu@gtiit.edu.cn

Y. Katayama

Tokyo National Research Institute for Cultural Properties, Tokyo, Japan
} 
of them, which has a potential biotechnological application in conservation of cultural heritage. The new proposed approach by focusing the microorganisms with identified biochemical function is more productive than a description of the community composition and assembly when assessing cultural heritage biodeterioration, and this provides basic and useful information for effective protection strategies and management.

Keywords Biodeterioration - Sandstone · Biofilms · Defoliation · Monuments · Sulfur-oxidizing $\cdot$ Ammonia-oxidizing $\cdot$ Salt attack

\section{Introduction}

Deterioration of the world cultural heritage and historic buildings is a result of both natural and/or anthropogenic contributors involving flora, fauna, and microorganisms as well as pollutants. Early investigations on cultural heritage biodeterioration were mainly focused on the isolation and identification of the cultural microorganisms for a description of them without specific function to the biodeterioration (May 2000). Such practice had been persisted before the application of polymerase chain reaction (PCR) to cultural heritage microbiology research to reveal the complex microbial community without culturing and isolation (Rölleke et al. 1998). The latest high-throughput sequencing and metagenomics provide a much deeper description of the microbial community and composition without culturing or isolation (May 2000; McNamara et al. 2006; Sterflinger and Pinar 2013; Zhang et al. 2019; Ma et al. 2020; Meng et al. 2020). This new approach also has some major weakness in its inability to identify the active microbes from the genomic DNA-based community analysis and, in addition, the active deteriorating ones are not identified from the community. Because of these, the advances made on knowing the community better have not translated to useful results on the deteriorating processes for a more effective management and prevention (Liu et al. 2020).

Microorganisms colonizing surfaces of cultural heritage can destruct the underlying materials through their influences on the physical, chemical, and bioreceptibility of the substratum materials, especially metabolic activities and biochemical reaction. Biofilms as a physical layer on the outer surface of cultural heritage alter the thermal property and moisture contents, which in turn have their impact on the biofilms and the activities of the microorganisms. The mechanisms involved in biodeterioration of natural sandstone and man-made materials include both abiotic and biological ones (Mansch and Bock 1998; Mitchell and Gu 2000; Warscheid and Braams 2000; Gu 2003; Liu et al. 2018a; Zhang et al. 2019; Ding et al. 2020; Liu et al. 2020). On the basis of microbiology and biochemistry, the initial colonization by the pioneering microorganisms to form biofilms on rock and stone surfaces can initiate a number of subsequent physical and chemical changes of the substratum materials, including the discoloration in appearance, alteration of porosity and vapor/moisture diffusivity in and out of the stone, accumulation of 
organic substances, acid production, solubilization and mobility of ions and salts, and mineral crystallization within the sandstone when interacting with the surrounding environments, e.g., drying (Ariño and Saiz-Jimenez 1996; Mitchell and Gu 2000; Warscheid and Braams 2000; Gaylarde et al. 2003; Perry et al. 2005; Gu and Mitchell 2013; Zhang et al. 2019). The tropical South Asia Cambodia, as an example, has a large collection of historical monuments and temples which are the most important existing records of the ancient civilizations, history, and humanity of people in the region of the world, including the Khmer (Freeman and Jacques 1999). Unfortunately, similar to many other cultural heritages around the world, these cultural heritage monuments are showing irreversible deterioration and destruction under the tropical climate conditions which support a colonizing microbial community and flora, and, more importantly, the active growth of various microorganisms under favorable conditions of the seasonality (Flores et al. 1997; Tayler and May 2000; Videla et al. 2000; Piñar et al. 2009; Motti and Stinca 2011; Gu 2012; Adamson et al. 2013; Keshari and Adhikary 2014; Meng et al. 2016, 2017; Liu et al. 2018b; Meng et al. 2020). In addition, a human dimension is increasing its contribution to the deterioration due to anthropogenic influences of pollutants and their deposition (Liu et al. 2018c, 2020; Meng et al. 2020). Microbial biofilms on stone surfaces alter the physical properties, thermal and water uptake and loss from the materials, and also the dynamics of soluble salt uptake and transport, into and out of the stone block, to initiate any physical stress and damage internally, e.g., crystallization of minerals to induce the pressure and delamination (Liu et al. 2018a; Zhang et al. 2019). Apart from the physical and chemical contributions to the damages, microbial biofilms on the stone monuments have been widely recognized for their negative impact mostly as the dominant views (Dornieden et al. 2000; Papida et al. 2000; Saiz-Jimenez and Laiz 2000; Warscheid and Braams 2000; Sterflinger and Prillinger 2001; Crispim and Gaylarde 2005; Li et al. 2007, Lan et al. 2010; Li et al. 2010; Meng et al. 2016; Sterflinger and Pinar 2013; Essa and Khallaf 2014; Meng et al. 2020).

Microbial community of Angkor monuments was analyzed initially with $16 \mathrm{~S}$ rRNA gene-based polymerase chain reaction (PCR) and clone library (Lan et al. 2010; Kusumi et al. 2013) and, at the same time, isolation and identification of bacteria and fungi of the sulfur cycle and capable of acid production were focused at the beginning to obtain a general overview of the microbial assembly and their role on the potential destruction of these sandstone monuments under the tropical climate (Meng et al. 2020; Mitchell and Gu 2000; Hosono et al. 2006; Li et al. 2010; Kusumi et al. 2011; Hu et al. 2013; Ding et al. 2020). With the non-invasive sampling technique developed at the Japan Space Agency, a spatial distribution of the different microbial groups was also visualized on selective sandstone bas relief of Bayon temple of Angkor Thom after taking sampling on the same selective locations for more than 40 times to construct the microbial community spatially by extraction of DNA and then PCR to obtain enough DNA for further community characterization to show the microbial communities over the sampling sequences as spatial information (Kusumi et al. 2013). 


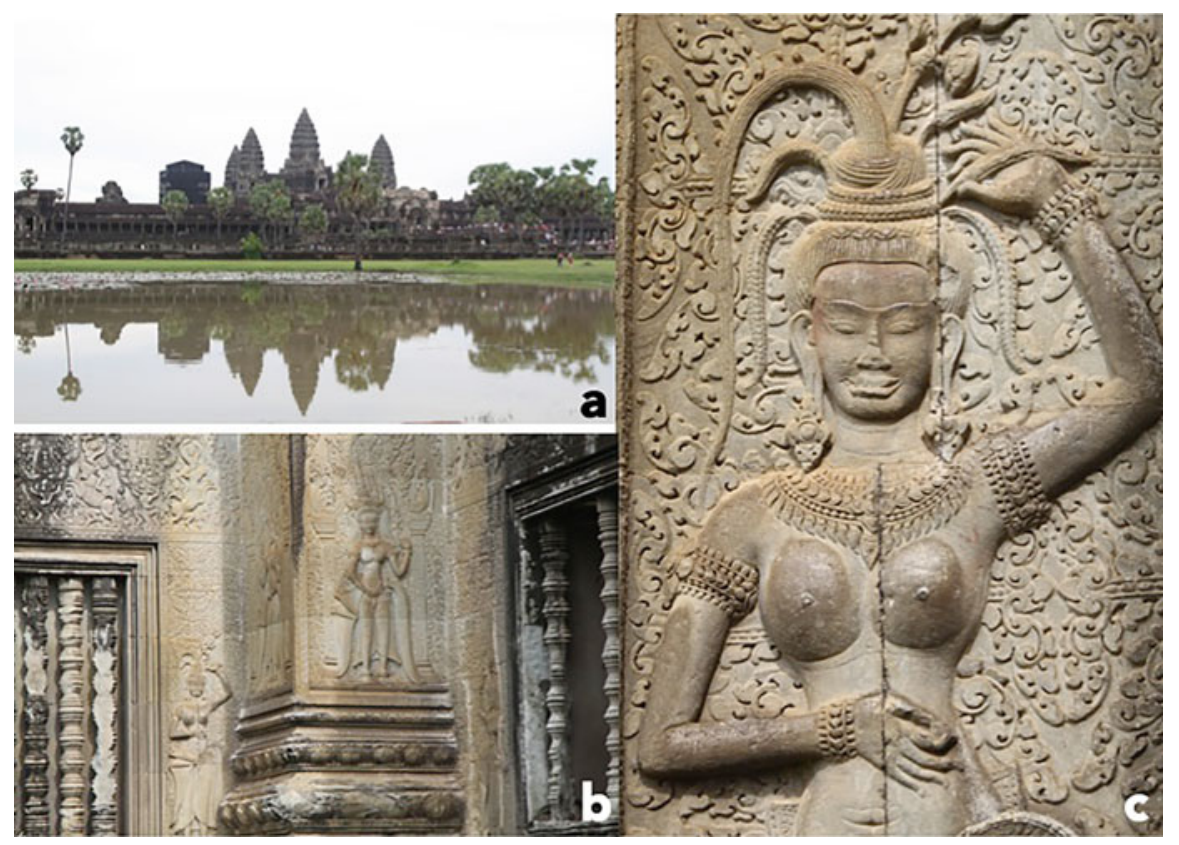

Fig. 2.1 Photographs of the UNESCO World Cultural Heritage Angkor Wat in Cambodia. A distance view of the central tower with surrounding ones (a); a corner section of the wall of the central tower (b); and a close up view of the carving of an Apsara on the sandstone wall (c)

Sulfur-oxidizing bacteria and fungi are detected at a number of Angkorian temples and they actively oxidize elemental $S\left(S^{0}\right)$ to produce acidity to contribute to the sandstone deterioration. Both mycobacteria and fungi were initially isolated and identified from Angkor monuments, and population dynamics were also monitored at a number of sites to show an active population of these microorganisms over a period of multiple years (Li et al. 2007, 2010; Kusumi et al. 2011). Lately, an accumulation of $\mathrm{NO}_{3}{ }^{-}$was initially observed at several locations of the sandstone temples in Cambodia and this has lead us to investigate the microbiological contributors for this phenomenon and also the possible causes to it (Meng et al. 2017; Ding et al. 2020). After several years of sampling and analyses, it then becomes clear that ammonia-oxidizing archaea (AOA) are much more abundant and also biologically active than ammonia-oxidizing bacteria (AOB) on these Angkor monuments in Cambodia using both genomic DNA first and then reverse transcripts of RNA in samples for $a m o A$ gene abundance quantification (Meng et al. 2016, 2017; Liu et al. 2018b; Meng et al. 2020). The analyses over several years at a number of monuments in the main cluster of Angkor Wat, Angkor Thom and also smaller ones at relatively short distance from the city Siem Reap, namely Phnom Krom and Wat Athvea, allow further confirmation on the observation for the ubiquity of the phenomenon (Fig. 2.1). The dominance of AOA at these temples is a wider occurring phenomenon, not restricted to a few selective cultural heritage sites (Meng et al. 
2017). Microorganisms on sandstone, especially those with specific biochemical function and capabilities, still reveal new information on the microbiology and biochemical reaction mechanisms for attack of sandstone differing from the community-based analysis without any specific biochemical function confirmed. A new analysis reveals that Comammox bacteria, oxidizing ammonia directly to $\mathrm{NO}_{3}{ }^{-}$ in a one-step reaction instead of the conventional two-step processes via nitrite as an intermediate, are also detected on Preah Vihear Temple (Ding et al. 2020).

\section{Microbial Colonization}

\subsection{Pioneering Colonizers and Colors}

Phototrophic microorganisms and lichens have major advantages over heterotrophic ones to initiate their colonization on fresh stone surfaces initially under the tropical climate conditions with plenty of sunlight and relatively high humidity. The description of these microorganisms and on different materials and niches is widely available (Sterflinger 2000; Lisci et al. 2003; Crispim et al. 2003; Liu et al. 2018c; Zhang et al. 2019; Liu et al. 2020). Due to the frequent rainfalls in monsoon season and plenty of sunlight, the sandstone under the tropical climate faces different challenges from those under temperate climate, which experience harsh winter and possibly hot summer. Under the tropical conditions, microbial activity is much more active and the life span of the sandstone materials for these monuments is consequently shortened compared to temperate climate (Meng et al. 2017, 2020). It is due to this fact that Angkor monuments are covered extensively with a wide range of microorganisms today showing in different colors (Fig. 2.1).

Natural sandstone contains very little organic carbon to support the active growth of heterotrophic population initially, but, after the initial colonization by the pioneering autotrophic microbial population on stones and rocks, the dead biomass and metabolites of them on the stone as a conditioning layer or crust become a readily available source of organic carbon for heterotrophic microorganisms to grow subsequently. Microbial colonization on inorganic stone and rock follows a general pattern and a series of sequences under the open environmental conditions (May 2000). Cyanobacteria, algae, and lichens are pioneering colonizers before active development of heterotrophic bacteria and then fungi (Gaylarde and Gaylarde 2000; Tayler and May 2000; Li et al. 2007; Kusumi et al. 2011, 2013; Liu et al. 2020). Lichens are mainly on stone of the open conditions under direct sunlight, but cyanobacteria and algae are abundant and active inside temples and monuments without direct sunlight but the moisture or water supply is constant.

Surface properties of the underlying sandstone can be altered in responses to thermal and hydrological processes after the colonization by microorganisms as biofilm, which in turn affect the physical and chemical characteristics of the sandstone during the succession and dynamics of different physiological and functional microbes (Gu et al. 1996; Gu and Mitchell 2013; Liu et al. 2016; Zhang et al. 2018; 
Ding et al. 2020). The main sequence of events after the initial microbial colonization on stone includes: (1) improvement of water retention in sandstone, immobilization of organic carbon onto surfaces and into sandstone through photosynthesis by the pioneering surface colonizers and (2) development of a population consisting of heterotrophic bacteria and fungi to form a more complex community composition of both autotrophic and heterotrophic microorganisms. Besides the biology, the surface properties are modified after microbial colonization for porosity, water regime (permeability, evaporation, and availability of water), and adhesion and trapping of atmospheric pollutants onto cultural heritage (Ariño and Saiz-Jimenez 1996; Mitchell and Gu 2000; Gu 2012; Liu et al. 2018a). Angkor Wat and the nearby temples constructed of sandstone are particularly susceptible to the colonization by different microorganisms over the past near one thousand years due to material and also the tropical conditions with plenty of sunlight and an active water cycle (Liu et al. 2018b). The phototrophic microorganisms including cyanobacteria and microalgae occur widely on the inside gallery walls of Angkor Wat and temples without direct sunlight, especially where moisture can be retained for a long period of time (Li et al. 2007; Lan et al. 2010; Kusumi et al. 2011; Meng et al. 2017; Zhang et al. 2019; Meng et al. 2020). Similar events are also observed on historic buildings frequently elsewhere (Crispim et al. 2003).

The different colors appearing on these monuments and buildings are closely associated with the material types, locations, dynamics of the microbial community development, seasonality, and also the ambient climate conditions. At any given selective location, the differences in color appearance are largely a result of the different microbial groups at different stages of their physiological growth and development on the specific sandstone type (Kusumi et al. 2013; Liu et al. 2018c; Zhang et al. 2019). Cultural heritage monuments and historic buildings often show different colors by microorganisms and also visible plants under natural conditions (Fig. 2.2). Cyanobacteria change its intensity of the green color from light to bright and then dark from early to maturity during the community development. The biofilms on Bayon temple of Angkor Thom show a change from the initial cyanobacteria and algae to the black fungi of the pigment-producing Ascomycetes at a late stage (Lan et al. 2010; Hu et al. 2013; Zhang et al. 2019). Many of the sandstone monuments in Southeast Asia and South Americas appear stained black or darker on the surface due to the fungi. At Angkor monuments, orange-pink pigmentation is associated with Lecythophora sp., dark brown with Cladosporium cladosporioides melanin, and black with Coniosporium apollinis melanin (Lan et al. 2010; Kusumi et al. 2013; Liu et al. 2018a). The pigmentation and deposition on sandstone surfaces have visual and aesthetical effects, but production of inorganic and organic acids by the colonizers has a much greater harm to the underlying sandstone and rock (May et al. 2000; Etienne and Dupont 2002; Liu et al. 2018b). 


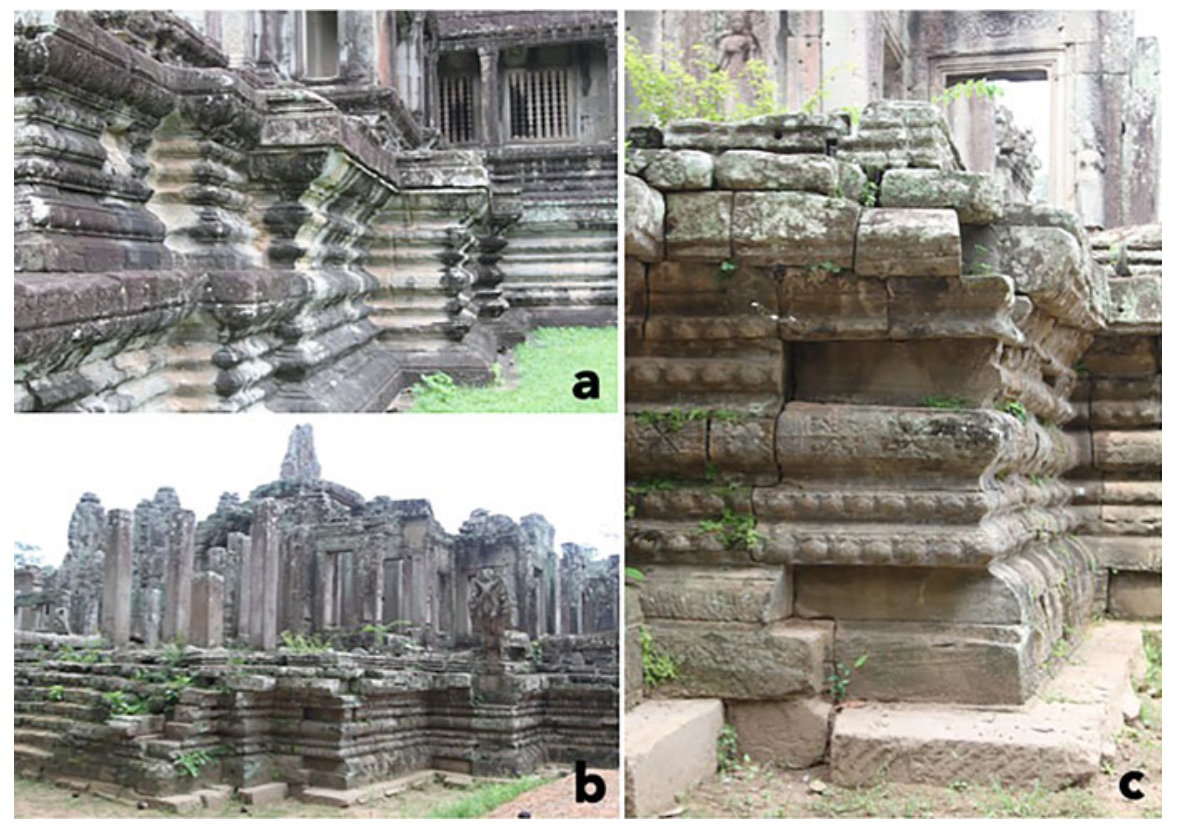

Fig. 2.2 Photographs of the sandstone foundation and current conditions at Angkor Wat (a) and Bayon temple of Angkor Thom from a distance (b) and a close up (c)

\subsection{Halophilic}

Sandstone and rock are unique niches and the microbial community and composition on sandstone are actually dominated by halophiles. Haloarchaea species are found on Angkor temples and the deteriorated sandstone walls of Bayon temple contain carbonates, chlorides, nitrates, sulfates, etc. as the main constituents (Uchida et al. 2000; Zhang et al. 2018). This information reminds of the early isolation and identification studies yielding a large number of common and known microorganisms, and such results shall be taken carefully for assessment of any damage to the sandstone because those microorganisms are not the dominant members of the indigenous community. The local conditions with sufficiently high concentration of salts enrich halotolerant and halophilic microorganisms to be the dominant members of the microbiome on sandstone, especially during the dry seasons. For example, the Haloarchaea species are a group of Euryarchaeota which are known for their preference for high salt concentrations (Kates 1978; May 2000). 


\subsection{Archaea}

Archaea as an independent domain of life is a significant milestone discovery in understanding of the biological world (Woese 1978). The non-methanogenic archaea have been expanded rapidly due to the many new phyla and superphyla of archaea discovered with the available high-throughput sequencing technology, metagenomics, and bioinformatics tools available (Liu et al. 2018a, b; Zhou et al. 2018 , 2019). The information has illuminated on new lineages of the archaea, but almost all of these new archaea are discovered mainly based on 16S rRNA gene sequences and metagenomes available. To further advance the physiology and biochemistry of these archaea, enrichment and isolation in pure cultures are the key step to advance the understanding on their ecological contribution and significance. As an example, AOA has only been recently detected as the dominant group responsible for oxidation of ammonia on sandstone monuments in Cambodia after observing accumulation of $\mathrm{NO}_{3}{ }^{-}$in sandstone (Meng et al. 2016, 2017). After analyzing samples from three different temples in Siem Reap of Cambodia, namely Bayon temple of Angkor Thom, Wat Athevea, and Phnom Krom, AOA was the dominant ones in the genomic DNA and also transcribed cDNA of the same set of samples, while AOB could only be detected at lower abundance and in a small fraction of the samples (Meng et al. 2016, 2017). Three PCR amplified sequences of Bayon temple were closely related to Nitrosopumilus maritimus, the first pure culture isolated from a tropical marine aquarium (Könneke et al. 2005; Walker et al. 2010), which is designated as Group I.1a. Major sequences of Phnom Krom samples fell into Group I.1a-associated closely affiliated with $\mathrm{Ca}$. Nitrosotalea devanaterra (Tourna et al. 2008, 2011) and into Group I.1b with $\mathrm{Ca}$. Nitrososphaera (Meng et al. 2016, 2017). The occurrence of these two groups is in good agreement with the fact that they are tolerant to low $\mathrm{pH}$ values (Hatzenpichler et al. 2008; Hatzenpichler 2012). Nitrosotalea and Nitrososphaera can grow when urea is available under acidic conditions (Kowalchuk et al. 2000; Laverman et al. 2001; Lu et al. 2012). In contrast, AOB were less abundant significantly compared with AOA on cultural heritage monuments under the tropical climate (Meng et al. 2016, 2017).

\section{Key Biochemical Processes of Biodeterioration}

\subsection{Carbon Sequestration}

As discussed above, phototrophic microorganisms are pioneer colonizers on fresh sandstone surfaces of cultural heritage under the tropical climate conditions and then the subsequent impacts from the microorganisms can be also variable due to the different species and the specific biochemical processes carried out by them $(\mathrm{Gu}$ and Mitchell 2013; Liu et al. 2018a). The most significant event is to sequestrate carbon 
dioxide from atmosphere initially onto sandstone to alter the exterior surface properties of the sandstone materials for an active dynamic advance of microorganisms with different physiological capabilities to provide chances for heterotrophic microorganisms to colonize over time. In addition to the natural cycle of carbon from inorganic to organic, anthropogenic pollution and pollutants cannot be ignored for their contribution to the development of a different microbial community that utilize the deposition to grow and also cause damage of the underlying materials (Mitchell and $\mathrm{Gu} 2000$ ).

\subsection{Nitrogen Transformation}

Among the different biochemical reactions of $\mathrm{N}$ cycle, $\mathrm{N}_{2}$-fixation and nitrification are two of the most significant ones on sandstone monuments of cultural heritage and historic buildings. At the same time as $\mathrm{CO}_{2}$ is sequestrated onto sandstone in biomass, $\mathrm{N}_{2}$ fixation is also taking place when cyanobacteria and algae are the dominant ones in the biofilm community (Zhang et al. 2019; Liu et al. 2020). For the nitrification or ammonia oxidation, the amoA genes of bacteria and archaea are phylogenetically distinct possessing different evolution and phenotypic characteristics (De Boer and Kowalchuk 2001; Nicol and Schleper 2006; Dodsworth et al. 2011). Abundance of the AOA amoA gene is much higher than that of AOB in selective habitat, including open ocean (Wuchter et al. 2006; Nakagawa et al. 2007; Beman et al. 2008; Cao et al. 2013), oil reservoirs (Li et al. 2011), acidic soils (Leininger et al. 2006; Nicol and Schleper 2006; Adair and Schwartz 2008; Nicol et al. 2008; Onodera et al. 2010), and estuaries and wetlands (Caffrey et al. 2007; Wang and Gu 2013).

Deteriorated sandstone samples are mainly comprised of decomposition products of minerals and clays from sandstone and components of biofilms at different development stages. Intrinsic sandstone properties dictating the colonization of microorganisms to form biofilms include mineral composition, porosity and permeability and retaining of water by the materials and susceptibility to dissolution (Ariño and Saiz-Jimenez 1996; Essa and Khallaf 2014). Ammonium released from decomposition of organic biomass and deposition from atmosphere is oxidized through microbial metabolism and AOA is the dominant group over AOB at several temples including Bayon temple of Angkor Thom, Wat Athevea, and Phnom Krom in Cambodia (Meng et al. 2016). AOA are easily detected at all sandstone monuments and the $\mathrm{pH}$ values of these samples are also generally low. Coupling the relative high concentration of $\mathrm{NO}_{3}{ }^{-}$detected with the low $\mathrm{pH}$ condition and the more abundant AOA than AOB, an active biochemical process of ammonia oxidation or nitrification is operative on these cultural heritage to result in an accumulation of biogenic nitric acid, which contributes to the biodeterioration of sandstone. At the same time, the accumulation of $\mathrm{NO}_{3}{ }^{-}$in sandstone of Angkor temples is also related to the inactive removal of the $\mathrm{NO}_{3}{ }^{-}$by denitrification and anammox of the relevant microorganisms (Ding et al. 2020). 


\subsection{Sulfur Transformation}

The four most important elements to life are carbon, nitrogen, phosphorus, and sulfur. Both nitrogen and sulfur metabolizing microorganisms are responsible for production of inorganic acids that can erode the sandstone and rock of cultural heritage. Previously, emphasis has been put more on corrosion initiated by sulfate/ sulfur-reducing bacteria and sulfur-oxidizing bacteria (Li et al. 2007; Li et al. 2010; Kusumi et al. 2013) and AOB (Sand and Bock 1991; Mansch and Bock 1998). After the discovery of ecological role of AOA, this group of archaea has also been detected on sandstone monuments using both DNA- and also RNA-based quantification of the amoA gene of this functional group of organisms (Meng et al. 2016, 2017). The abundance of AOA was higher than that of $\mathrm{AOB}$, implying that $\mathrm{AOA}$ is a major contributor to the deterioration of sandstone (discussed above). In addition, sulfuroxidizing bacteria and fungi are also detected on sandstone cultural heritage and their population is proportional to the sampling site where the damage is the most severe (Li et al. 2010; Kusumi et al. 2011). Based on these results, special attention shall be given to the microorganisms involved in sulfur cycling to effectively protect cultural heritage. Sulfate was detected in the liquid medium inoculated with deteriorated sandstone samples, and the chemolithoautotrophic Mycobacterium spp. (Kusumi et al. 2011) and 19 sulfur-oxidizing fungal strains (Li et al. 2010) capable of sulfur oxidation were isolated from the deteriorated sandstones in Angkor Wat, Bayon, and Phnom Krom temples to indicate their contribution.

Sources of sulfur may be from the biofilm and preformed biomass and also fecal materials of bats and wild animals living in these temples. In the early part of the previous century, heterotrophic fungi were confirmed for sulfur oxidation and various fungi can oxidize $S^{0}$ for energy to grow, including Trichoderma harzianum and Aspergillus niger. A number of fungal genera are capable of oxidizing inorganic sulfur compounds, but the biochemical sulfur oxidation pathway and enzymes involved are still not known clearly. Fusarium solani strain THIF01, isolated from Angkor monuments, is capable of utilizing $S^{0}$ chemolithoautotrophically as the energy source ( $\mathrm{Li}$ et al. 2010). This fungus contains an endobacterium Bradyrhizobium sp. which has sulfur oxidation capability, but the bacterium-free culture (strain THIF01BF) that was obtained by treatments with antibiotics of strain THIF01 showed chemolithoautotrophic growth with $S^{0}$ (Xu et al. 2018).

\subsection{Other Elements}

Other elements are also important to life and the cycling of nutrients by microorganisms in different ways. They can serve in dissimilatory and assimilatory biochemical processes depending on the element types and the specific microorganisms involved producing transformation products and biomass, respectively (Ehrlich 2002). As an example, iron in the environment can play a role to participate in the 
corrosion and biodeterioration of stone materials (Warscheid and Braams 2000), but the relative significance of this biochemical process compared with major elements $\mathrm{C}, \mathrm{N}$, and $\mathrm{S}$ shall be much smaller or insignificant. Because of this, involvement and contribution of microorganisms utilizing $\mathrm{Fe}$ and $\mathrm{Mn}$ and other elements to deterioration of stone are not further discussed here, but their significance in revealing new biochemical processes shall not be underestimated in future research as a focus area.

\section{Interactions Among Sandstone, Microbiota, and the Local Environment}

\subsection{Material Types}

Sandstone is a porous material of natural origin and is not strong enough compared to other stone and rock from igneous formation. Such property of this material makes it to be very susceptible to attack by weathering through water absorption and freezeand-thaw cycle. Colonization by microflora and plants adds another dimension to the stability challenge to sandstone in open climate conditions (Liu et al. 2018b, 2020). Under tropical conditions of Southeast Asia and South America, both sunlight and water are plenty to provide the basic requirements for phototrophic life forms of plants and microorganisms to colonize and grow on surfaces. As soon as the initial colonization on surfaces is established, e.g., lichens either the initial protection or further damage of the materials can take place through the specific microorganisms actively metabolizing on surfaces of stone (Liu et al. 2018c, 2019). Both autotrophic and heterotrophic ones can actively grow in the surface colonizing community and alter the materials through their metabolic processes and the metabolites. Such progress and development of the community over time on sandstone surfaces maintain an active and dynamic community on the sandstone surfaces and allow sequestration of inorganic $\mathrm{CO}_{2}$ from atmosphere and cycling of nutrients through the life cycle of different microorganisms and their biomass coupling with the seasonality.

Sandstone is interacting with the surrounding environment, including water, air, microbiota, and anthropogenic contributors. Among all of them, temperature and availability of water play a crucial role in limiting or promoting microbial colonization and biofilm formation on sandstone under favorable conditions of the tropics (Liu et al. 2018a). Because of the porosity of sandstone and biofilm formation to prevent more quick exchanges of water between the surrounding and those retained inside sandstone, increasing retention of water holding in sandstone supports more active microbial colonization and growth to result in more damage of stone from biological activities (Zhang et al. 2019). At the same time, movement of water containing soluble salts by siphon effects promotes formation of mineral crystals upon drying, which initiates external surface defoliation progressively to lead to 


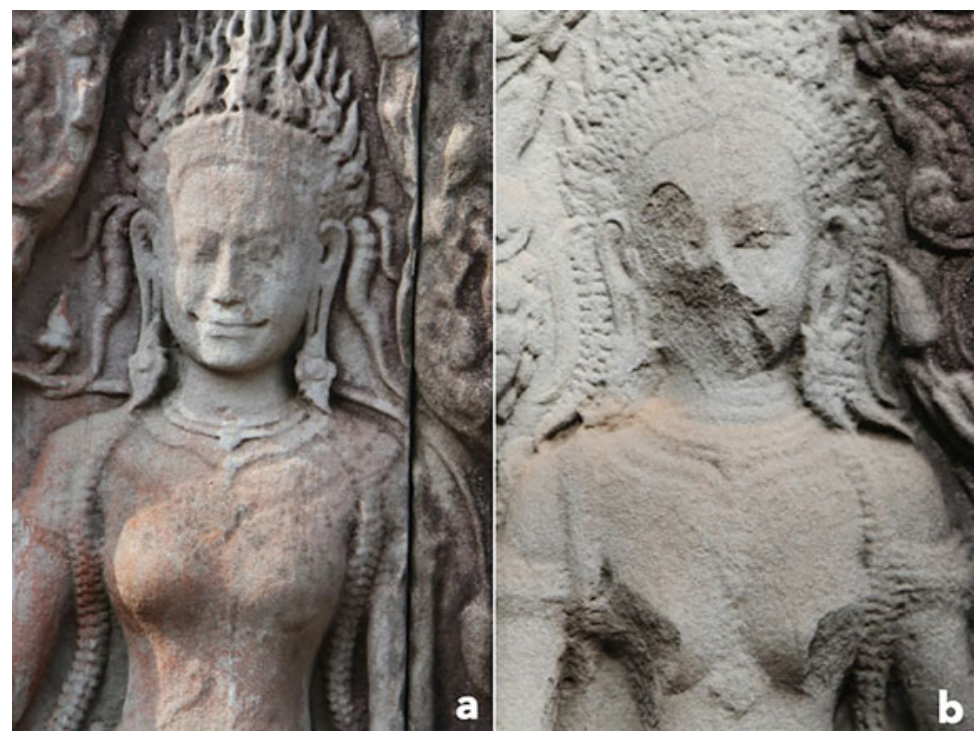

Fig. 2.3 Photographs of Devatas carved on sandstone columns showing differences in conditions and destructions with more red pigment deposition (a) and more severe damage (b) at Bayon temple of Angkor Thom

significant weakening of the sandstone mechanical strength to collapse over time. Such phenomena are widely observed on monuments of cultural heritage and buildings showing the progression to defoliation and destabilization of sandstone structure (Fig. 2.3). This kind of damage and destruction is widespread at stone monuments in Southeast Asia and, at Angkor Wat in particular, the sandstone columns for structural support at the gallery section show much severe damage in the basal portion closer to the floor level where rainwater can be retained for longer period of time. This suggests that water management is an important issue in the protection of world cultural heritage for an effective and long-term plan (Liu et al. 2019).

\subsection{Available Nutrients and Pollutants}

World cultural heritage in tropical regions is much more susceptible to deterioration mainly due to the availability of sunlight and more importantly the rainwater onto sandstone which contains abundant minerals to allow microbial colonization and growth with the available water. In the tropical regions after the initial microbial settlement and colonization on sandstone and rock, a bioactive layer covers the exterior surface of sandstone and temples/monuments to buffer the underling materials with the surrounding environment from protection and damage at different stages of the development (Liu et al. 2018b). Initially oligotrophic niche on 
sandstone becomes enriched through phototrophic growth to sequestrate organic substances onto and into the surface layer of sandstone, in doing so the local conditions are altered from the oligotrophic to organic carbon rich one. After this transformation, heterotrophic microorganisms become the dominant population including both bacteria and fungi to change the color of sandstone from its original gray or light brown to dark and black. Fresh microbial biofilm consisting of algae and cyanobacteria is reported (Lan et al. 2010) and the different colors and pigmentations on sandstone wall are associated with different microbial groups at Bayon and Angkor Wat (Kusumi et al. 2013). These microorganisms need to be further evaluated for their specific role in the bioprotection and/or biodeterioration at different development stages considered to advance our comprehensive understanding of their specific role over time to provide more accurate information for future management of cultural heritage effectively. Subsequent results indicate the acid attack initiated by microbial oxidation of $\mathrm{S}^{\circ}$ from reduction product of $\mathrm{H}_{2} \mathrm{~S}$ or sulfate (Li et al. 2007, 2010). More recent research information showed that ammonia oxidation is an active biochemical reaction mechanism carried out mainly by AOA at several temples in Cambodia (Meng et al. 2016, 2017). This is a new development for further assessment of its flux and activities so that future management can be made considering such results in the conservation plan. It is certain that more contributors are involved in the biodeterioration of sandstone monuments and destruction of valuable galleries and bas relief, key factors shall be identified and ranked according to the extent of destruction by each of them so that management can be focused on a few most important ones first to monitor the effectiveness over time to verify the conservation results.

Cultural heritage of monuments and temples is in constant exchange with the surrounding environmental conditions, both water and biological attacks may take place simultaneously. In addition, the increasing anthropogenic pollution cannot be ignored in the current and future investigation and protection. With the pre-existing biofilms and modified surfaces of sandstone to increase the roughness of the surfaces and porosity, the color change enhances thermal property of the underlying sandstone to absorb solar radiation, but emits less due to the biofilm layer especially when water contents in the surface layer are high. In addition, the pollutants in the air can be deposited and trapped by the porous biofilms on surfaces to be potential sources of organic carbon to selective biofilm microorganisms capable of utilizing them to grow. The active surface layer coated on sandstone is of significant research interest to investigate the physical and biochemical processes actively involved and also the dynamics of them spatially and temporally to gain further insights of this microniche and system for new discoveries. 


\section{Protection Strategies}

As cultural heritage and historic buildings are unique in their design, cultural identity, Angkor monuments as an example have a very important role in the understanding of Khmer culture and civilization history. Without them, it is a great loss to the world humanity for the future generations to appreciate and comprehend the world history for an understanding of the rich culture and civilization in Southeast Asia. It is apparent that the deterioration and damage of these monuments and temples as world cultural heritage are constant threats to the future protection of these monuments (Fig. 2.4), therefore effective protective measures, based on scientific data, shall be formulated, tested, and implemented to preserve them for the future generations.

Deterioration of stone monuments is a result of natural decomposition process involving physical, chemical, and biological ones, protection cannot stop these processes (Liu et al. 2020), but delay their progression under specific conditions. With such information in mind, effective management and protection strategies shall be the focus on identification of the key processes involved for destruction and rank them in order for management strategy than an overall community analysis without identification of the detrimental processes. The mechanisms of the most active processes together with the responsible microorganisms shall be delineated to

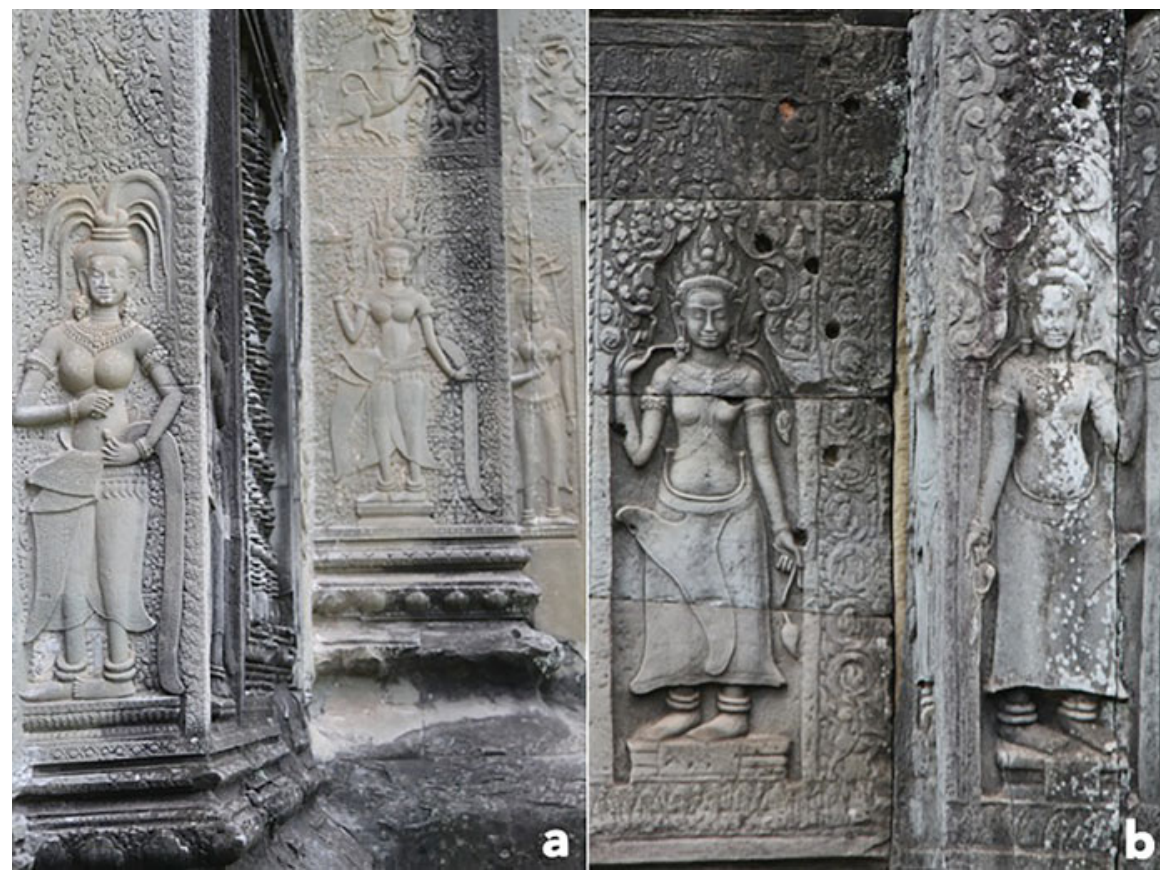

Fig. 2.4 Photographs of Apsaras of Angkor Wat (a) and Devatas at Bayon temple (b) showing different conditions on the same sandstone of different quality initially 
advance the knowledge for protection and management. Biofilms on sandstone have different roles at different stages of the colonization and biofilm development, such understanding is vitally important to a deeper understanding of biofilm dynamics and its relationship with the integrity of sandstone (Warscheid and Braams 2000; Gu et al. 2011; Liu et al. 2018c; Zhang et al. 2019). As a matter of fact, physical removal of biofilms is not going to solve the deterioration issue from microbial activity, but accelerate the damage because of removing the protective biofilms to expose the underlying surfaces for another cycle of colonization and biofilm development. Microorganisms can also play a role in control of biofilms. Fungi appearing on matured biofilms are correlated with the peeling off of old biofilms, which has potential to be further developed into biotechnology for biological control and cleaning of colonized surfaces (Gleeson et al. 2005; Hu et al. 2013).

The biochemical processes should be identified when evaluating the susceptibility of sandstone to microorganisms for colonization and biodeterioration (Meng et al. 2017; Zhang et al. 2019). Phototrophic microorganisms initially establish on the sandstone surfaces to be the pioneering biofilms when water and mineral nutrients are readily available from the substratum. Apart from the external factors of the environment, sandstone has reasonable porosity to allow water retention and also promotion of microbial colonization. At the same time, the small pores also trap nutrients from atmospheric deposition containing dust and microbes to promote biosusceptibility and attack of sandstone. Currently, major efforts have been given to the analysis of the microbial community with the latest available sequencing technology independent of culturing and isolation, but the biochemical functions by the selective members of the community need to be delineated so that initiation for damage of the cultural heritage can be prevented and limited with means available. The interfaces between sandstone surface and biofilms remain a hotspot for biological activity and biochemical processes when analysis of cultural heritage is the target (Ma et al. 2015; Wu et al. 2017; Kakakhel et al. 2019). Biofilm and plants can establish the cultural heritage over time when routine maintenance is not carried out effectively. A close monitoring and clearance can achieve a good protection from weeds and plants, which otherwise would grow into the sandstone to cause dislocation of the stone blocks and collapse of the structure (Liu et al. 2018a; 2019). To protect them, maintenance work shall be conducted to remove newly grown plants and weeds regularly so that no large plants can be established and remain on these structures.

Maintenance work also involves repair of the damaged and destructed structure and stone pieces. This may involve the use of chemical adhesive and consolidants, so that the repaired stone may last longer when exposed to both the ambient climate conditions and invasive growth of microorganisms, particularly fungi ( $\mathrm{Gu}$ et al. 2011; Wu et al. 2017; Zhang et al. 2018). At the same time, water repellants are also used to seal the stone from natural rainwater and keep dry to avoid water-associated damage. But such practice has a serious potential drawback in that trapped water inside the sandstone is more destructive than those without such protections used so nature regulates the water movement (Sterflinger and Pinar 2013; Liu et al. 2018b; Sterflinger et al. 2018). Considering these factors, sandstone monuments and 
temples are better kept away from water, especially stagnant water, if possible or let natural rainwater to uptake and drain freely from the structures when raining or drying accordingly. However, after the formation of biofilm on surfaces, these exchange processes for water are being slowed down for both into and out of the stone, resulting in less efficient movement of water to initiate damage of the stone through both biofilm development and also salting effects.

Polymeric materials are increasingly used in applications including conservation and protection of cultural heritage. Some of the successful cases are usually restricted to specific environmental conditions of museums, but such information is not widely reported for the specificity of the materials to the selective outdoor environmental conditions. Misuse of such information has resulted in disaster in conservation work due to outbreaks of microbial growth after application of consolidants or even antimicrobials to cultural heritage exposed to outdoor conditions (Gu 2003; Gu et al. 2011; Wu et al. 2017; Liu et al. 2018c; Kakakhel et al. 2019). Polymeric materials may perform well under harsh conditions including high humidity and temperature, but such polymeric materials are generally very difficult to apply as consolidants because of their high viscosity, insolubility in even solvents, and associated colors. In contrast, those polymers that have been used successfully in museums are generally not resistant to metabolism by indigenous microorganisms because fungi are airborne and particularly capable of attacking high strength and engineering polymers due to fillers, additives, and plasticizers (Gu 2003; Mitchell and $\mathrm{Gu}$ 2000; Gu et al. 2011; Gu 2012).

Inorganic materials have many good applications in construction and protection of building. Such practice has been proven successful when the candidate materials are used to appropriate niche and conditions. For example, lime is a common material to apply to surfaces of building to protect the biomaterials from insect attack. Such materials are also available now on the market, but the composition of the commercially available products contains not only lime but also additives, including polymeric materials, cellulose, and cellulose esters, which are biodegradable and cause serious biofilm establishment and growth on surfaces of structure (Gu and Mitchell 2013).

New materials and technologies are also becoming available through research and innovation, and some of the promising ones include nanomaterials and technology for effective protection against fast growth of colonized biofilm microorganisms (Liu et al. 2018a). At the same time, corroding chemical and biochemical processes may be inhibited through intervention of chemical treatment or approaches to advance the protection more effectively.

Antimicrobial chemicals are commercially available for inhibiting the growth of microorganisms under selective or specific conditions, e.g., disease pathogen control and eradication, but the available information indicates that successive applications promote the development of resistance in microorganisms, which is a major public health concern when the resistant genes are enclosed on plasmids that are more readily transmitted among the same species and also between different species. It is unlikely to achieve an effective long-term control using a single or few chemicals. Conversely, when selecting candidate chemicals, the current testing protocols for 
screening are problematic because the testing conditions are mainly based on inhibitory testing in liquid cultures, not the application surface or the environmental niche conditions. The very little resemblance between the target conditions and the laboratory testing ones results in non-effectiveness after applications in situ on cultural heritage (Gu 2003; Essa and Khallaf 2014; Liu et al. 2018b, 2020).

\section{Summary}

Stone cultural heritage and historic buildings are susceptible to colonization by microorganisms of a wide range of physiological characteristics depending on the environmental conditions and also the stage of the development. Both the specific active microorganisms and also their physiological functions shall be identified and elucidated for a better and more specific understanding on the deterioration biochemical processes and mechanisms involved for effective protection of the sandstone temples/monuments. Microorganisms involved in carbon, nitrogen, and sulfur cycles are the most important ones, especially the biochemical processes that generate acidic or corrosive products to erode sandstone and dissolve the minerals. On Angkor temples/monuments, sulfur-oxidizing bacteria and fungi, ammoniaoxidizing archaea, and also phototrophic cyanobacteria and algae are identified as priority members for investigations of their biochemical contribution to the deterioration. Related processes, e.g., denitrification, anammox, and comammox, are also important for the comprehensive knowledge on the accumulation of nitrate in many sandstone monuments.

Physical and environmental factors of the materials and hydrological dynamics shall not be ignored from the biology for protection and management of cultural heritage sites because they affect the biology on stone fundamentally and then the stability of the stone. Equipped with the information on the materials of cultural heritage and buildings, biology, and biochemistry, preservation strategies can be formulated for protection of sandstone by taking advantage of the latest development and technologies in chemistry, nanomaterials, and molecular biology.

Acknowledgements This project was supported by Safeguarding of Bayon Temple of Angkor Thom (JASA, Japan), APSARA Authority of Cambodian Government, the UNESCO/Japanese Funds-in-Trust for the Preservation of the World Cultural Heritage, and partially by a Hong Kong RGC GRF Grant (No. 17302119).

Ethical Statement Conflict of Interest: All authors declare that they have no conflict of interest in this study.

Ethical Approval: This article does not contain any studies with human participants or animals performed by any of the authors of this investigation.

Sampling at temples was granted by APSARA Authority of Cambodian Government, the Kingdom of Cambodia. 


\section{References}

Aair KL, Schwartz E (2008) Evidence that ammonia-oxidizing archaea are more abundant than ammonia-oxidizing bacteria in semiarid soils of northern Arizona, USA. Microbiol Ecol 56:420-426

Adamson C, McCabe S, Warke PA, McAllister D, Smith BJ (2013) The influence of aspect on the biological colonization of stone in Northern Ireland. Int Biodeterior Biodegradation 84:357-366

Ariño X, Saiz-Jimenez C (1996) Factors affecting the colonization and distribution of cyanobacteria, algae and lichens in ancient mortars. In: Riederer J (ed) 8th International Congress on Deterioration and Conservation of Stone. Möller Druck und Verlag, Berlin, pp 725-731

Beman JM, Popp BN, Francis CA (2008) Molecular and biogeochemical evidence for ammonia oxidation by marine Crenarchaeota in the Gulf of California. ISME J 2:429-441

Caffrey JM, Bano N, Kalanetra K, Hollibaugh JT (2007) Ammonia oxidation and ammoniaoxidizing bacteria and archaea from estuaries with differing histories of hypoxia. ISME J $1: 660-662$

Cao H, Auguet JC, Gu J-D (2013) Global ecological pattern of ammonia-oxidizing archaea. PLoS One 8:e52853

Crispim C, Gaylarde C (2005) Cyanobacteria and biodeterioration of cultural heritage: a review. Microbiol Ecol 49:1-9

Crispim CA, Gaylarde CC, Gaylarde PM, Copp J, Neilan BA (2003) Molecular biology for investigation of cyanobacterial populations on historic buildings in Brazil. In: Saiz-Jimenez C (ed) Molecular biology and cultural heritage. Balkema, Lisse, pp 141-143

De Boer W, Kowalchuk G (2001) Nitrification in acid soils: micro-organisms and mechanisms. Soil Biol Biochem 33:853-866

Ding X, Lan W, Li Y, Wu J, Hong Y, Urzi C, Katayama Y, Ge Q, Gu J-D (2020) Microbiome and nitrate removal by denitrifying and anammox on the sandstone Preah Vihear temple in Cambodia revealed by metagenomics and N-15 isotope. Appl Microbiol Biotechnol 104(22):98239837. https://doi.org/10.1007/s00253-020-10886-4

Dodsworth JA, Hungate BA, Hedlund BP (2011) Ammonia oxidation, denitrification and dissimilatory nitrate reduction to ammonium in two US Great Basin hot springs with abundant ammonia-oxidizing archaea. Environ Microbiol 13:2371-2386

Dornieden T, Gorbushina AA, Krumbein WE (2000) Biodecay of cultural heritage as a space/timerelated ecological situation - an evaluation of a series of studies. Int Biodeterior Biodegradation 46:261-270

Ehrlich HL (2002) Geomicrobiology. Marcel Dekker, New York, p 768

Essa AM, Khallaf MK (2014) Biological nanosilver particles for the protection of archaeological stones against microbial colonization. Int Biodeterior Biodegradation 94:31-37

Etienne S, Dupont J (2002) Fungal weathering of basaltic rocks in a cold oceanic environment (Iceland): comparison between experimental and field observations. Earth Surf Proc Land 27:737-748

Flores M, Lorenzo J, Gómez-Alarcón G (1997) Algae and bacteria on historic monuments at Alcala de Henares, Spain. Int Biodeterior Biodegradation 40:241-246

Freeman M, Jacques C (1999) Ancient Angkor. River Books, Ltd., Bangkok

Gaylarde C, Silva MR, Warscheid T (2003) Microbial impact on building materials: an overview. Mater Struct 36:342-352

Gaylarde PM, Gaylarde CC (2000) Algae and cyanobacteria on painted buildings in Latin America. Int Biodeterior Biodegradation 46:93-97

Gleeson DB, Clipson N, Melville K, Gadd GM, McDermott FP (2005) Characterization of fungal community structure on a weathered pegmatitic granite. Microb Ecol 50:360-368

$\mathrm{Gu}$ J-D (2003) Microbiological deterioration and degradation of synthetic polymeric materials: recent research advances. Int Biodeterior Biodegrad 52:69-91. https://doi.org/10.1016/S09648305(02)00177-4 
Gu J-D (2012) Biofouling and prevention: corrosion, biodeterioration and biodegradation of materials. In: Kultz M (ed) Handbook of environmental degradation of materials, 2nd edn. Elsevier, Waltham, pp 243-282

Gu J-D, Mitchell R (2013) Biodeterioration. In: Rosenberg E, DeLong EF, Lory S, Stackebrandt E, Thompson F (eds) The prokaryotes: applied bacteriology and biotechnology. Springer, New York, pp 309-341

Gu J-D, Ford TE, Mitchell R (1996) Fungal degradation of concrete. In: Sand W (ed) DECHEMA monographs. Biodeterioration and biodegradation. VCH, Frankfurt, pp 135-142

Gu J-D, Ford TE, Mitton B, Mitchell R (2011) Microbial degradation of materials: general processes. In: Revie W (ed) The Uhlig corrosion handbook, 3rd edn. John Wiley \& Sons, New York, pp 351-363

Hatzenpichler R (2012) Diversity, physiology, and niche differentiation of ammonia-oxidizing archaea. Appl Environ Microbiol 78:7501-7510

Hatzenpichler R, Lebedeva EV, Spieck E, Stoecker K, Richter A, Daims H, Wagner M (2008) A moderately thermophilic ammonia-oxidizing crenarchaeote from a hot spring. Proc Natl Acad Sci U S A 105:2134-2139

Hosono T, Uchida E, Suda C, Ueno A, Nakagawa T (2006) Salt weathering of sandstone at the Angkor monuments, Cambodia: identification of the origins of salts using sulfur and strontium isotopes. J Archaeol Sci 33:1541-1551

Hu H, Katayama Y, Kusumi A, Li SX, Wang J, de Vries RP, Gu J-D (2013) Occurrence of Aspergillus allahabadii on sandstone at Bayon Temple, Angkor Thom, Cambodia. Int Biodeterior Biodegradation 76:112-117

Kakakhel MA, Wu F, Gu J-D, Feng H, Shah K, Wang W (2019) Controlling biodeterioration of cultural heritage objects with biocides: a review. Int Biodeterior Biodegrad 143:104721. https:// doi.org/10.1016/j.ibiod.2019.104721

Kates M (1978) The phytanyl ether-linked polar lipids and isoprenoid neutral lipids of extremely halophilic bacteria. Prog Chem Fats Other Lipids 15:301-342

Keshari N, Adhikary SP (2014) Diversity of cyanobacteria on stone monuments and building facades of India and their phylogenetic analysis. Int Biodeterior Biodegradation 90:45-51

Könneke M, Bernhard AE, José R, Walker CB, Waterbury JB, Stahl DA (2005) Isolation of an autotrophic ammonia-oxidizing marine archaeon. Nature 437:543-546

Kowalchuk GA, Stienstra AW, Heilig GHJ, Stephen JR, Woldendorp JW (2000) Molecular analysis of ammonia-oxidising bacteria in soil of successional grasslands of the Drentsche A (The Netherlands). FEMS Microbiol Ecol 31:207-215

Kusumi A, Li XS, Katayama Y (2011) Mycobacteria isolated from Angkor monument sandstones grow chemolithoautotrophically by oxidizing elemental sulfur. Front Microbiol 2:104

Kusumi A, Li X, Osuga Y, Kawashima A, Gu J-D, Nasu M, Katayama Y (2013) Bacterial communities in pigmented biofilms formed on the sandstone bas-relief walls of the Bayon Temple, Angkor Thom, Cambodia. Microbes Environ 28:422

Lan W, Li H, Wang WD, Katayama Y, Gu J-D (2010) Microbial community analysis of fresh and old microbial biofilms on Bayon temple sandstone of Angkor Thom, Cambodia. Microb Ecol 60:105-115

Laverman A, Speksnijder A, Braster M, Kowalchuk G, Verhoef H, van Verseveld H (2001) Spatiotemporal stability of an ammonia-oxidizing community in a nitrogen-saturated forest soil. Microb Ecol 42:35-45

Leininger S, Urich T, Schloter M, Schwark L, Qi J, Nicol G, Prosser J, Schuster S, Schleper C (2006) Archaea predominate among ammonia-oxidizing prokaryotes in soils. Nature 442:806-809

Li H, Mu B-Z, Jiang Y, Gu J-D (2011) Production processes affected prokaryotic amoA gene abundance and distribution in high-temperature petroleum reservoirs. Geomicrobiol J 28:692-704 
Li X, Arai H, Shimoda I, Kuraishi H, Katayama Y (2007) Enumeration of sulfur-oxidizing microorganisms on deteriorating stone of the Angkor monuments, Cambodia. Microbes Environ 23:293-298

Li XS, Sato T, Ooiwa Y, Kusumi A, Gu J-D, Katayama Y (2010) Oxidation of elemental sulfur by Fusarium solani strain THIF01 harboring endobacterium Bradyrhizobium sp. Microb Ecol 60:96-104

Lisci M, Monte M, Pacini E (2003) Lichens and higher plants on stone: a review. Int Biodeterior Biodegradation 51:1-17

Liu J-F, Wu W-L, Yao F, Wang B, Zhang B-L, Mbadinga SM, Gu J-D, Mu B-Z (2016) A thermophilic nitrate-reducing bacterium isolated from production water of a high temperature oil reservoir and its inhibition on sulfate-reducing bacteria. Appl Environ Biotechnol 1(2):3542. https://doi.org/10.18063/AEB.2016.02.004

Liu X, Meng H, Wang Y, Katayama Y, Gu J-D (2018a) Water is the critical factor to establishment biological and stability of Angkor temple sandstone in Southeast Asia. Int Biodeterior Biodegrad 133:9-16. https://doi.org/10.1016/j.ibiod.2018.05.011

Liu X, Li M, Castelle CJ, Probst AJ, Zhou Z, Pan J, Liu Y, Banfield JF, Gu J-D (2018b) Insights into the ecology, evolution and metabolism of the widespread Wosearchaeotal lineage. Microbiome 6:102

Liu X, Pan J, Liu Y, Li M, Gu J-D (2018c) Diversity and distribution of Archaea in global estuarine ecosystems. Sci Total Environ 637:349-358

Liu Y-F, Qi Z-Z, Shou L-B, Liu J-F, Yang S-Z, Gu J-D, Mu B-Z (2019) Anaerobic hydrocarbon degradation in candidate phylum 'Atribacteria' (JS1) inferred from genomics. ISME J 13:23772390. https://doi.org/10.1038/s41396-019-0448-2

Liu X, Koestler RJ, Warscheid T, Katayama Y, Gu J-D (2020) Microbial biodeterioration and sustainable conservation of stone monuments and buildings. Nature Sustainability (accepted)

Lu L, Han W, Zhang J, Wu Y, Wang B, Lin X, Zhu J, Cai Z, Jia Z (2012) Nitrification of archaeal ammonia oxidizers in acid soils is supported by hydrolysis of urea. ISME J 6:1978-1984

Ma Y, Zhang H, Du Y, Tian T, Xiang T, Liu X, Wu F, An L, Wang W, Gu J-D (2015) The community distribution of bacteria and fungi on ancient wall paintings of the Mogao Grottoes. Sci Rep 5:7752

Ma W, Wu F, Tian T, He D, Zhang Q, Gu J-D, Duan Y, Wang W, Feng H (2020) Fungal diversity and potential biodeterioration of mural paintings on bricks in two 1700-year-old tombs of China. Int Biodeterior Biodegrad 152:104972. https://doi.org/10.1016/j.ibiod.2020.104972

Mansch R, Bock E (1998) Biodeterioration of natural stone with special reference to nitrifying bacteria. Biodegradation 9:47-64

May E (2000) Stone biodeterioration. In: Mitchell R, McNamara CJ (eds) Cultural heritage microbiology: fundamental studies in conservation science. American Society for Microbiology, Washington, DC, pp 221-234

May E, Papida S, Abdulla H, Tayler S, Dewedar A (2000) Comparative studies of microbial communities on stone monuments in temperate and semi-arid climates. In: Ciferri O, Tiano P, Mastromei G (eds) Of microbes and art: the role of microbial communities in the degradation and protection of cultural heritage. Kluwer Academic Publishers, Dordrecht, pp 49-62

McNamara CJ, Perry TD, Bearce KA, Hernandez-Duque G, Mitchell R (2006) Epilithic and endolithic bacterial communities in limestone from a Maya archaeological site. Microb Ecol 51:51-64

Meng H, Luo L, Chan HW, Katayama Y, Gu J-D (2016) Higher diversity and abundance of ammonia-oxidizing archaea than bacteria detected at the Bayon Temple of Angkor Thom in Cambodia. Int Biodeterior Biodegradation 115:234-243

Meng H, Katayama Y, Gu J-D (2017) Wide occurrence and dominance of ammonia-oxidizing archaea than bacteria at three Angkor sandstone temples Bayon, Phnom Krom and wat Athvea in Cambodia. Int Biodeterior Biodegradation 117:78-88 
Meng H, Zhang X, Katayama Y, Ge Q, Gu J-D (2020) Microbial diversity and composition of the Preah Vihear temple in Cambodia by high-throughput sequencing based on both genomic DNA and RNA. Int Biodeterior Biodegrad 149:104936

Mitchell R, Gu J-D (2000) Changes in the biofilm microflora of limestone caused by atmospheric pollutants. Int Biodeterior Biodegrad 46:299-303

Motti R, Stinca A (2011) Analysis of the biodeteriogenic vascular flora at the Royal Palace of Portici in southern Italy. Int Biodeterior Biodegradation 65:1256-1265

Nakagawa T, Mori K, Kato C, Takahashi R, Tokuyama T (2007) Distribution of cold-adapted ammonia-oxidizing microorganisms in the deep-ocean of the northeastern Japan Sea. Microbes Environ 22:365-372

Nicol GW, Schleper C (2006) Ammonia-oxidising Crenarchaeota: important players in the nitrogen cycle? Trends Microbiol 14:207-212

Nicol GW, Leininger S, Schleper C, Prosser JI (2008) The influence of soil pH on the diversity, abundance and transcriptional activity of ammonia oxidizing archaea and bacteria. Environ Microbiol 10:2966-2978

Onodera Y, Nakagawa T, Takahashi R, Tokuyama T (2010) Seasonal change in vertical distribution of ammonia-oxidizing archaea and bacteria and their nitrification in temperate forest soil. Microbes Environ 25:28-35

Papida S, Murphy W, May E (2000) Enhancement of physical weathering of building stone by microbial population. Int Biodeterior Biodegradation 64:305-317

Perry IV TD, McNamara CJ, Mitchell R (2005) Biodeterioration of stone, scientific examination of art: modern techniques in conservation and analysis. Sackler National Academy of Sciences Colloquium, pp 72-86

Piñar G, Ripka K, Weber J, Sterflinger K (2009) The microbiota of a sub-surface monument the medieval chapel of St. Virgil (Vienna, Austria). Int Biodeterior Biodegradation 63:851-859

Rölleke S, Witte A, Wanner G, Lubitz W (1998) Medieval wall paintings-a habitat for archaea: identification of archaea by denaturing gradient gel electrophoresis (DGGE) of PCR-amplified gene fragments coding for $16 \mathrm{~S}$ rRNA in a medieval wall painting. Int Biodeterior Biodegradation 41:85-92

Saiz-Jimenez C, Laiz L (2000) Occurrence of halotolerant/halophilic bacterial communities in deteriorated monuments. Int Biodeterior Biodegradation 46:319-326

Sand W, Bock E (1991) Biodeterioration of mineral materials by microorganisms - biogenic sulfuric and nitric acid corrosion of concrete and natural stone. Geomicrobiol J 9:129-138

Sterflinger K (2000) Fungi as geologic agents. Geomicrobiol J 17:97-124

Sterflinger K, Pinar G (2013) Microbial deterioration of cultural heritage and works of art - tilting at windmills? Appl Microbiol Biotechnol 97:9637-9646

Sterflinger K, Prillinger H (2001) Molecular taxonomy and biodiversity of rock fungal communities in an urban environment (Vienna, Austria). Anton Leeuw 80:275-286

Sterflinger K, Little B, Pinar G, Pinzari F, de los Rios A, Gu J-D (2018) Future directions and challenges in biodeterioration research on historic materials and cultural properties. Int Biodeterior Biodegradation 129:10-12

Tayler S, May E (2000) Investigations of the localisation of bacterial activity on sandstone from ancient monuments. Int Biodeterior Biodegradation 46:327-333

Tourna M, Freitag TE, Nicol GW, Prosser JI (2008) Growth, activity and temperature responses of ammonia-oxidizing archaea and bacteria in soil microcosms. Environ Microbiol 10:1357-1364

Tourna M, Stieglmeier M, Spang A, Könneke M, Schintlmeister A, Urich T, Engel M, Schloter M, Wagner M, Richter A (2011) Nitrososphaera viennensis, an ammonia oxidizing archaeon from soil. Proc Natl Acad Sci U S A 108:8420-8425

Uchida E, Ogawa Y, Maeda N, Nakagawa T (2000) Deterioration of stone materials in the Angkor monuments, Cambodia. Eng Geol 55:101-112

Videla HA, Guiamet PS, Gomez de Saravia S (2000) Biodeterioration of Mayan archaeological sites in the Yucatan peninsula, Mexico. Int Biodeterior Biodegradation 46:335-341 
Walker C, de La Torre J, Klotz M, Urakawa H, Pinel N, Arp D, Brochier-Armanet C, Chain P, Chan P, Gollabgir A (2010) Nitrosopumilus maritimus genome reveals unique mechanisms for nitrification and autotrophy in globally distributed marine crenarchaea. Proc Natl Acad Sci U S A 107:8818-8823

Wang YF, Gu J-D (2013) Higher diversity of ammonia/ammonium-oxidizing prokaryotes in constructed freshwater wetland than natural coastal marine wetland. Appl Microbiol Biotechnol 97:7015-7033

Warscheid T, Braams J (2000) Biodeterioration of stone: a review. Int Biodeterior Biodegrad 46:343-368

Woese CR (1978) Bacterial evolution. Microbiol Rev 51:221-271

Wu F, Duan Y, Wang W, He D, Gu J-D, Feng H, Chen T, Liu G, An L (2017) The microbial community characteristics and biodeterioration assessment of ancient wall paintings in Maijishan Grottoes, China. PLoS One 5:12, e0179718

Wuchter C, Abbas B, Coolen MJL, Herfort L, van Bleijswijk J, Timmers P, Strous M, Teira E, Herndl GJ, Middelburg JJ, Schouten S, Damste JSS (2006) Archaeal nitrification in the ocean. Proc Natl Acad Sci U S A 103:12317-12322

Xu H-B, Tsukuda M, Takahara Y, Sato T, Gu J-D, Katayama Y (2018) Lithoautotrophical oxidation of elemental sulfur by fungi including Fusarium solani isolated from sandstone Angkor temples. Int Biodeterior Biodegrad 126:95-102. https://doi.org/10.1016/j.ibiod.2017. 10.005

Zhang G, Gong C, Gu J, Katamaya Y, Ji-Dong G (2019) Biodeterioration and the mechanisms involved of sandstone monuments of World Cultural Heritage sites in tropical regions. Int Biodeter Biodegr 143:104723

Zhang X, Ge Q, Zhu X, Deng M, Gu J-D (2018) Microbiological community analysis of the Royal Palace in Angkor Thom and Beng Mealea of Cambodia by Illumina sequencing based on $16 \mathrm{~S}$ rRNA gene. Int Biodeterior Biodegradation 134:127-135

Zhou Z, Liu Y, Li M, Gu J-D (2018) Two or three domains: a new view of the tree of life in the genomics era. Appl Microbiol Biotechnol 102:3049-3058

Zhou Z, Liu Y, Lloyd KG, Pan J, Yang Y, Gu J-D, Li M (2019) Genomic and transcriptomic insights into the ecology and metabolism of benthic archael cosmopolitan, Thermoprofundales (MBG-D archaea). ISME J 13:885-901

Open Access This chapter is licensed under the terms of the Creative Commons Attribution 4.0 International License (http://creativecommons.org/licenses/by/4.0/), which permits use, sharing, adaptation, distribution and reproduction in any medium or format, as long as you give appropriate credit to the original author(s) and the source, provide a link to the Creative Commons license and indicate if changes were made.

The images or other third party material in this chapter are included in the chapter's Creative Commons license, unless indicated otherwise in a credit line to the material. If material is not included in the chapter's Creative Commons license and your intended use is not permitted by statutory regulation or exceeds the permitted use, you will need to obtain permission directly from the copyright holder.

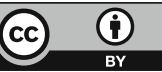

